\title{
On Surveying the Whole Legal Forest
}

\author{
Robert A. Kagan
}

I am always amazed by newspaper reports of the way that geologists and space scientists draw complex conclusions about the origin or nature of a planet from data sent back by a probe of one tiny part of the planet's surface. They seem to have a lot of confidence in their underlying theories. The same is not true for sociolegal scholars. We don't have full-fledged theories about how legal systems actually work, and hence it seems risky to make big generalizations about a system as a whole based on a study of one or two legal institutions or processes.

Making generalizations about the "law in action" for whole legal systems is especially risky if the subject is the United States, with its 50 different state legal systems, from Mississippi to Montana to Massachusetts, and with its proliferation of different kinds of courts, law enforcement bodies, police departments, administrative tribunals, and regulatory agencies, state, federal and local. Small wonder that most empirical sociolegal scholarship is relatively narrowly focused on specific legal policy areas and processes. While these case studies are immensely valuable, occasionally it seems worthwhile to use the scholarly close-ups of particular clumps of trees to draw some wide-angle conclusions, however tentative, about the shape and dynamics of the legal forest. That, however quixotic the effort, is what I sought to do in Adversarial Legalism: The American Way of Law (hereinafter AL). But just as Don Quixote needed the skeptical realism of Sancho Panza, the essays on $\mathrm{AL}$ in this issue, paying close attention to text, empirical detail, and analytic precision, serve as a reminder of the pitfalls attending the quest for generality. Yet I am not quite willing to don the Quixote costume. In this essay I will argue that $\mathrm{AL}$, even if a bit ambitious, is reasonably realistic, and that the questions raised by the other essays raise meaningful but not

Robert A. Kagan is professor of political science and law, University of California, Berkeley. Many thanks to David Johnson for organizing the Law and Society Association panel that led to this exchange. 
insuperable obstacles to its pursuit of generalizations about the American legal system.

My mission in AL was not to provide a systematic comparison between the legal system of the United States and that of any particular country. The book's focus is overwhelmingly on the United States; most of the research cited and discussed is about American legal processes alone. The many passages in AL that describe a particular foreign legal process are not meant to serve as a comprehensive portrait of, or comparison with, that country's legal system as a whole. Rather, I use these comparative sociolegal studies, each of which provides an empirically grounded portrait of one particular process in the United States and another country, to highlight what is distinctive (and often troublesome) about the parallel American approach. ${ }^{1}$ Instead of "systematic holistic comparison," we might call AL's method "comparison for the sake of domestic insight"- a common approach in comparative law scholarship. That is, my goal in AL was to build generalizations about the American legal system, not that of any other country. The question is whether the evidence in $\mathrm{AL}$ is adequate to support the generalizations offered. The essays on $\mathrm{AL}$ in this issue question some of the book's empirical generalizations and its evaluation of American adversarial legalism. In so doing, they evoke some of the fundamental challenges that beset cross-national comparison of legal systems and generalizing about legal systems as a whole. I will proceed in four sections, discussing (1) the conceptualization of adversarial legalism; (2) the evidentiary basis for AL's claims of American exceptionalism; (3) the consequences of (and evaluation of) American adversarial legalism; and (4) explanations of American exceptionalism.

\section{ANALYZING “ADVERSARIAL LEGALISM”}

Any effort to generalize about legal processes, particularly in crossnational perspective, requires the establishment of conceptual categories, dimensions, or variables that serve as a metric for description. To that end, the first chapter of AL lays out a typology of modes of policy implementation and dispute resolution. One dimension contrasts legally formal and informal methods. The second dimension posits that modes of policy implementation and dispute resolution, formal or informal, vary between those that are more hierarchically organized and controlled and those that are more participatory and party driven. Thus "adversarial legalism" is defined as a legally for-

1. Here's a homey analogy. Parent scolds his child Henry, "Your friend Homer never does that!" Parent doesn't want to trade Henry for Homer, who may lack many of Henry's special virtues and may have other problems that parent doesn't know about. Homer is used as an "object lesson," a way of pointing out that feasible alternatives to Henry's course of action really do exist. 
mal and party-driven method. It is distinguished first of all from nonlegalistic modes of policy implementation and dispute resolution, such as those that rely on "expert or political judgment" (hierarchical) or "negotiation or mediation" (party driven). ${ }^{2}$

Second, among legally formal methods, adversarial legalism differs from "bureaucratic legalism"-which, as I define it, emphasizes hierarchical recruitment and supervision of legal decision makers, uniform implementation of centrally devised rules, a restricted role for judicial policymaking, official responsibility for fact finding, judicial domination of the adjudicative process, and hence a smaller role for lawyers and legal advocacy than is common in the United States. Adversarial legalism, in contrast, is characterized by litigant and lawyer activism, fragmented authority, and greater responsiveness (at all levels) to legal and political advocacy.

Bureaucratic legalism is epitomized by day-to-day case processing by the Social Security Administration, in which government officials push individual cases through the dies and templates constituted by detailed regulations and official forms (Ochoa 1997). But also tending toward that idealtype, as stated in AL (p. 11):

are German and French courts, where bureaucratically recruited and embedded judges-not the parties' lawyers, and not lay juries-dominate both the evidence-gathering and the decision-making processes (Langbein, 1994). Similarly, in contrast to American criminal prosecutors' offices, in which individual assistant district attorneys usually make their own judgments about which charges to make and bargain with defense counsel about how much to reduce them in return for guilty pleas, prosecutors in Japan are subject to detailed rules and close hierarchical supervision concerning the investigation of facts, determination of the proper charge, and the recommendation of penalties (Johnson 1998).

The conceptual scheme in AL seeks to capture not merely methods of adjudication and individual case decision making but also "modes of policy implementation," that is, the ways in which political entities seek to ensure that official norms and policies will be translated into action, resolving the disputes that arise in that regard. Here the distinction between adversarial legalism and the other ideal-types may require some further illustration. In $\mathrm{AL}$, for example, I report that:

In the 1970s and 1980s, the incidence of asbestos-related diseases among Dutch workers was five to ten times as high as in the United States. Dutch law authorizes tort claims against employers. As of 1991,

2. On the "informal" side of the typology, "expert or political judgment" emphasizes the authority of hierarchically empowered decision makers, whereas "negotiation and mediation" are party driven, and hierarchical authority is absent, distant, or weak. 
almost 200,000 asbestos-based tort cases had been filed in the U.S. Fewer than ten had been filed in The Netherlands. The primary reason, according to Harriet Vinke and Ton Wiltagen (1992: 12,17), is that "in the Netherlands employees get reasonable benefits in a non-confrontational way" - that is, through the social security system. Disabled Dutch workers are entitled to all needed medical care and lifelong benefits equal to 70 or 80 percent of their lost earnings, without having to prove an employer or product manufacturer did anything wrong. In the Dutch non-fault-based collective system, Vinke and Wilthagen note, compensation is modest in amount, but far more certain and consistent than in the adversarial American tort system. (P. 126) $)^{3}$

In terms of my typology, The Netherlands (like many other welfare states that provide universal health care) has a more centralized, bureaucratically administered method of compensating victims. Governments in the United States, repeatedly rejecting that approach, have placed more reliance on a method (tort litigation in decentralized courts, employing jury trials) that is more institutionally fragmented, less hierarchically organized and controlled. Moreover, it is characterized by lawyer-driven fact finding and normative argument and by judicial responsiveness: it was entrepreneurial lawyers and politically appointed judges (not legislators or bureaucrats) who established and elaborated the basic principles of liability, damages, and aggregation of claims, authorizing asbestos victims to circumvent the bureaucratically organized workers' compensation system.

Here is another example. Compared to western European democracies, legislatures and high courts in the United States have deliberately given courts and environmental advocacy organizations a much larger role in the administration of environmental policies. They have done so by fragmenting administrative authority and hedging it with detailed substantive and procedural rules, enabling a wide variety of affected interests to challenge regulatory decisions in courts. Thus lawyers, litigation, and legal formalism play a larger role in regulatory policy implementation in the United States than in other democracies, where that process generally emphasizes a combination of political and expert judgment, and informal consultation with affected interests (Vogel 1986; Badaracco 1985; Brickman, Jasaoff, and Ilgen 1985; Kagan and Axelrad 2000; Verweij 2000). In the criminal process, too,

3. Because the average mesothelioma victim dies one year after the disease has become manifest, the actual amounts paid to asbestos victims in The Netherlands are far less than the average tort recovery in the United States (Vinke and Wilthagen 1992, 18). The higher rate of asbestos-related disease in The Netherlands does not stem from the absence of adversarial legalism there. It reflects the greater importance of shipbuilding in the Dutch economy. America's tougher tort law did not prevent the epidemic of asbestos-related disease in the United States. In both countries, the abandonment of asbestos use was a consequence of direct government regulation. 
in the United States, where prosecutors and police are recruited and governed in a politically decentralized way, defense lawyers and courts have played a major role in making and enforcing legal norms concerning police practices-in contrast to the more hierarchical systems of western Europe and Japan, where legislatures make the rules of criminal procedure (Bradley 1993) and supervision is more in the hands of more centralized police and prosecutorial bureaucracies (Frase 1990). ${ }^{4}$

Thus in AL, I use the term adversarial legalism to refer both to the "dayto-day practice of adversarial legal contestation," and to a complex of legal institutions, mechanisms, rights, and rules that facilitate or encourage adversarial, party-dominated legal contestation-what might be called "the structures of adversarial legalism." To offer an analogy, Americans use the term baseball to refer both to (1) a set of institutionalized concepts, structures and rules, and (2) to a day-to-day practice - the act of playing baseball. We may think of "baseball" when we look down from an airplane on a wintry urban landscape dotted with baseball fields, even though at that moment the actual rate of baseball playing on those diamonds may be nil.

Like the farmer in Field of Dreams who built a baseball diamond in a cornfield on the faith that "they will come," the structures, institutions and rules of adversarial legalism represent an invitation to the actual practice of adversarial legalism. They create opportunities and incentives for angry disputants, organized political and ideological interest groups, and entrepreneurial lawyers. If they are mobilized often enough, the structures of adversarial legalism constitute meaningful threats to a range of businesses, organizations, and government agencies. This is true even if full-scale adversarial litigation occurs in only a small percentage of all potential disputes. We don't know how high the actual rate of adversarial legalism in practice has to be to work its deterrent effects, but we do know that American corporate employers, physicians, and government agencies tend to overestimate the actual risk of being hauled into court (Edelman et al. 1992). ${ }^{5}$

The ideal-typical modes of policy implementation and dispute resolution discussed in $\mathrm{AL}$ represent a menu from which (at least in principle) political and legal systems can choose. Typically, contemporary democracies rely on some of each. Politically driven adversarial litigation sometimes oc-

4. Another example contrasting more hierarchical and American adversarial legalistic methods is provided by Takao Tanase's (1990) comparison of the compensation of motor vehicle accident victims in Japan and the United States, discussed by Sanders in this issue.

5. Nelken (2003) asks whether there is a "a logical or only a contingent connection" between adversarial legalism as an adjudicative or dispute-resolving structure and adversarial legalism as a mode of governance or policy implementation. The text above, I think, suggests that the answer is "both." The structures of adversarial legalism, by their very nature, create incentives for adversarial legalism in practice, but the rate is contingent on a variety of additional factors, from the actual incidence of difficult-to-resolve disputes to the policies and choices and funding of lawyers (see the excellent discussion by Epp ([998] of the organizational machinery of rights litigation), business firms, and governmental agencies. 
curs in Great Britain, Germany (Boyle 1998), The Netherlands (Niemeijer 1989) and even in Japan (Upham 1987). In the United States, adversarial legalism is by no means ubiquitous or the first option. The Internal Revenue Service is characterized primarily by bureaucratic legalism. Most municipal land use permits are decided via expert judgment (by planning officials) or political judgment (by elected zoning boards or city councils). Adjudication in American small claims courts is hierarchical, rather than adversarial, and family courts often operate on the basis of the expert judgment of judges and social workers. In the United States, as almost everywhere, negotiation and mediation are more prevalent than formal litigation, for it is usually vastly quicker and cheaper. The U.S. Social Security Disability Insurance program, as described by Mashaw (1983), deals with difficult cases t'nrough a complex mixture or sequence of expert judgment, bureaucratic legalism, and what I would call adversarial legalism. Of course, adversarial legalism can be and sometimes is injected into tax administration and local land use disputes. One can thus compare systems of policy implementation and dispute resolution in terms of the ease and the frequency with which adversarial legalism (as practice) can intrude upon or displace the other modes.

\section{AMERICAN LEGAL EXCEPTIONALISM}

Linked by a global communications system, politicians, journalists, advocacy groups, and electorates in all economically advanced democracies lament basically the same kinds of injustices, environmental harms, and technological hazards. There are some national differences, to be sure, but comparative studies of environmental and product safety regulation repeatedly find that the substantive differences in regulatory standards in rich democracies are not very different and that the control measures imposed on or adopted by business firms often are about the same (Kagan and Axelrad 2000; Gunningham, Kagan, and Thornton 2003). Although penalties for violations usually are tougher in the United States, the same is true of criminal and commercial law. The "exceptionalism" discussed in AL, therefore, relates to what might be called "legal style"-the ways in which laws are articulated and implemented, legal disputes are adjudicated, violations punished, and arguments made and resolved.

But at that level, too, Epp (2003) questions whether the American legal system is really quite as distinctive as $\mathrm{AL}$ contends. Litigation and judicial activism have increased in other countries too, he points out. In addition, he suggests that since the actual rate of adversarial litigation is not high in many spheres of American law and life, AL really shows only that the perceived threat of litigation is greater in the United States. I don't quite agree. But Epp's arguments bring up some interesting problems. 


\section{Litigation Rates}

Sociolegal scholars have always struggled with the challenge of comparing national litigation rates (Galanter 1983; leetswart 1990). Aggregate comparisons based on the nationwide ratio of court filings to 100,000 people are misleading. They are distorted by cross-national differences in the jurisdictions of the courts whose filings rate provide numerators for the calculation of the rates. They are distorted further by differences in the extent to which nations funnel some kinds of litigation into specialized tribunals. The most useful method of comparison, in my view, are detailed cross-national studies of litigation in particular policy domains, such as Erhard Blankenburg's (1994) comparison of debt collection and other specific kinds of litigation in The Netherlands and Rhineland-Westphalia, or the Jeffrey Sellers (1995) study of land use development projects in New Haven, Connecticut, Montepelier, France, and Frieburg, Germany. In AL, I list and discuss more than 34 studies that compare how the United States and at least one other economically advanced democracy deal with a particular kind of social or legal problem, such as cleaning up hazardous wastes (Church and Nakamura 1993; Axelrad 2000) or reducing worker exposure to dangerous vinyl chloride fumes (Badaracco 1985). Only two-the Sellers study and Feldman's (2000) comparison of litigation concerning HIV-contaminated blood in the United States, France and Japan-run counter to the American exceptionalism hypothesis. The rest strongly support that claim.

That is, the comparative studies I have been able to find clearly indicate that the United States more often employs a set of legal structures, rules, and practices that facilitate or encourage adversarial litigation. These engines of adversarial legalism include ready access to the courts, contingency fees, class actions, large money damages, broad judicial authority to reverse governmental decisions, a politically appointed judiciary, and relatively higher levels of legal malleability and uncertainty. That doesn't mean that Americans always or usually mobilize the machinery of adversarial legalism. ${ }^{6}$ But several comparative policy-specific studies show not only that fear of litigation is greater in the United States but also that litigation really is more common in the United States than in parallel policy areas in the other countries. Other comparative studies show that even when governments relegate legal or regulatory decisions to administrative bodies, in the United States parties more often challenge the administrative decisions in court. ${ }^{7}$

6. Thus AL's findings concerning American exceptionalism are not undercut by Epp's observation that in absolute terms, Americans confronted with land use disputes (citing Brisbin, Hunter, and Leyden 2002) do not litigate at the drop of a hat - as is the case with other kinds of disputes as well (Miller and Sarat 1981; Hensler et al, 1991).

7. Comparative studies showing that administrative or regulatory issues more often end up in court in the US include Jost (1998) (medical plan coverage); Somaya (2000) (patent processing and defense); Brickman et al. 1985 (regulatory rule making); Church and Naka- 
It also is important to pay attention to qualitative differences in litigation, not merely the quantitative rate, for in the United States, litigation is more adversarial, unpredictable, costly and threatening. As Epp (2003) notes, Markesinis (1990) says that tort litigation rates in Germany approach those in the United States But tort litigation in Germany is dominated by judges, not adversarial lawyers. There, without the many delays and redundancies associated with preparation for jury trials, cases are processed more expeditiously, damages are much lower, and the system is much cheaper for disputants (Langbein 1985; Blankenburg 1994). Similarly, in France and Germany, litigation concerning development projects of the kind discussed by Sellers (1995) is channeled into specialized administrative courts; in these bureaucratic forums, litigation differs from the more adversarial and costly litigation that occurs in American courts of general jurisdiction. ${ }^{8}$ For example, Welles and Engel (2000) found that when a multinational firm sought to build or expand municipal solid waste disposal sites in California, Pennsylvania, Great Britain, and The Netherlands, it encountered litigation by project opponents in all four jurisdictions. But the litigation in the United States was more protracted, vastly more expensive in terms of lawyers' fees, ${ }^{9}$ and resulted in settlements requiring much larger "side payments" to project opponents.

W. A. Bogart (2002), writing from a Canadian perspective, provides an especially sweeping and thoughtful review of the comparative sociolegal literature. He comes to a similar conclusion:

There are, of course, similarities between America and other countries. Yet the United States employs law in a particular way. The predominance of courts, the emphasis on individualism, the adversarialness, the enshrinement of rights, and the punitiveness for criminal offences set that society apart. In quantity and quality the United States is an outlier regarding the role of law. $(2002,114)$

\section{Convergence?}

Is American legal exceptionalism disappearing? Globalization, Nelken suggests, is pushing other nations toward legal convergence on the American

mura (1993) (hazardous waste cleanup). Sellers (1995), cited by Epp, is the only exception 1 know of.

8. Thus Sellers (1995) reports that although the rate at which development projects result in litigation is rather similar in New Haven, Montpelier, and Frieburg, it is only in the United States that developers regularly are accompanied by and rely on lawyers in their dealings with land use authorities.

9. In California, the firm spent $\$ 15$ million on legal services, addressing two major administrative appeals and three extended lawsuits. In Pennsylvania, the firm's legal bills amounted to "only" $\$ 1.45$ million, but in England, where the litigation occurred in an administrative forum, lawyers bills were $\$ 137,000$ and in The Netherlands, where lawyers are not required in administrative appeals, the firm spent less than $\$ 50,000$ on legal services. 
model. Indeed, as noted earlier, cross-national studies of environmental regulation show remarkable similarities in basic regulatory norms (Kagan and Axelrad 2000). ${ }^{10}$ But in terms of national styles of law and implementation, too, there is some evidence that other nations increasingly are turning to litigation and courts to enhance governmental accountability and protect individual rights. Thus Epp (2003) discusses the growing activism of constitutional courts in numerous countries and changes in tort litigation in Great Britain. As I have argued elsewhere (Kagan 1997), globalization and neoliberal policy changes have made economic life in many nations more competitive and turbulent. Interactions and transactions among strangers have increased. For political and social minorities, the costs of political organization have declined. Distrust of bureaucrats and experts has grown, and political power has become more fragmented. In all those respects, other democracies have started to look more like the United States. They are likely, therefore, to experience the demands for greater legal responsiveness that have characterized American politics and hence to experience growth in litigation.

Convergence toward American-style adversarial legalism, however, does not mean convergence on or with the American way of law (Kagan 1997). Compared to a quarter century ago, more Americans play soccer, and Italians more often play basketball. Hence one might say that the trend lines for the popularity of those sports are converging, in the sense that the differences are narrowing. But those lines remain very far apart and are likely to remain so. Similarly, imagine adversarial legalism (both as a set of structures and as a practice) varying, on a national basis, between "high" and "low," as shown in figure 1.

high U.S." U.S. $^{2} \quad$ Nation $X^{2} \quad$ Nation $X^{11}$ low

Figure 1.

National Rates of Adversarial Legalism

Even if adversarial legalism were to increase in Nation X (England, Japan, Italy, etc.) between time 1 and time 2, and even if the incidence of adversarial legalism decreased in the United States from $t^{1}$ to $t^{2}$, there would still be a very substantial gap between the two countries. In reality, we have no aggregate measures of where countries as a whole stand on this dimension. But my sense-based on the long list of comparative studies cited and discussed in $\mathrm{AL}$ - is that the figure roughly captures both the trend over

10. In a recent study of the regulation of pulp and paper mills in Australia, Canada, New Zealand, and the states of Georgia and Washington in the United States, my colleagues and I found that there was more variation in levels of pollutants in mill effluents within jurisdictions than across jurisdictions, due to convergence in the terms of mills' regulatory permits (and social pressures) in all the countries (Gunningham, Kagan and Thornton 2003). 


\section{LAW AND SOCLAL INQUIRY}

the last decade and the relative position of the United States and western Europe.

For example, Epp (2003) makes a good deal of England's increase in tort litigation (and in nervousness about it). Yet the latest detailed comparative study I know of shows how the American legal system provides much stronger institutional supports and incentives for malpractice litigation than Britain's (Quam et al. 1987). " Thus even if malpractice suits increased in England in the 1990s, it is unlikely that levels in Great Britain have approached American levels. Moreover, the nature and impact of British malpractice litigation almost surely remains muted compared to the U.S. variety of the species. In England (as in most economically advanced democracies), most of the past and future cost of medical care for malpractice victims is covered by the national health care system, while "pain and suffering" damages are moderate, set forth in legal rules applied by judges rather than set by juries under elastic guidelines (Schwartz 1991).

Moreover, for variety of reasons, I think it quite unlikely that Western European democracies will greatly close the gap in the future. This is all in the realm of speculation, of course, but it seems to me rather a long shot that western European countries, abandoning long-entrenched legal traditions, will adopt key structures and supports of American-style adversarial legalism, such as (1) an overtly politically appointed (rather than a professionally recruited) judiciary; (2) a mode of legal education and practice that, rather than mostly emphasizing black letter law, strongly endorses adversarial lawyering and lawyerly and judicial creativity; (3) wide-ranging judicial powers to mandate and monitor institutional reforms; (4) trial by jury and open-ended rules for calculating damages in tort cases; (5) judge-made constitutional rules and intensive use of the exclusionary rule as principal modes of regulating police behavior; or (6) pre-enforcement judicial review of new regulations (Kagan 1997). ${ }^{12}$

The degree of convergence, I have argued, will be limited because of trans-Atlantic differences in political structure and legal-political culture (Kagan 1997). European nations, built around parliamentary government,

11. Victims of medical malpractice in Great Britain, Quam et al. (1987) point out, face much larger obstacles than their U.S. counterparts in obtaining legal services and expert witnesses in malpractice cases and far weaker incentives to sue, because the money damages recoverable under British law are much smaller. See also Schwartz (1991).

12. In western Europe, particularly as the influence of the EU grows, one might expect some increased adversarial legalism in policy realms such as regulation of corporate finance and business transactions, environmental regulation, and claims by women and ethnic minorities (Kagan 1997). Thus as Epp notes, Great Britain's law of sex discrimination, modeled on the U.S. Civil Rights Act, authorizes enforcement by private suits as well as by government agency, as does the Austrian law on sexual harassment. On the other hand, Saguy (2000) finds that the French law against civil harassment has not generated anywhere close to the same volume of sexual harassment cases as has occurred in the United States, with its more aggressive array of lawyers, and I suspect that that disparity in legal mobilization will continue to apply to most of Europe. 
cohesive political parties, and strong national bureaucracies, differ substantially from the United States, which has a political tradition of fragmented political power, relatively undisciplined political parties, and distrust of "big government." 13 Consider just one way in which this matters. Due to the fragmentation of lawmaking authority in the United States and a uniquely freewheeling system of campaign finance, the American legislative process is especially penetrable by organized interest groups of all ideological stripes (Moe 1989). In consequence, significant pieces of legislation often are jerrybuilt, as detailed provisions are inserted at the last minute to win the support recalcitrant legislators, interest groups, or the chief executive. The laws that emerge are more often more confusing, less coherent, than those that emerge from the British parliament, for example (Atiyah and Summers 1987). Separation of powers means that interest groups and political leaders in the United States quite rationally worry that the bureaucracy that implements a key statute may be dominated by appointees of a competing political party; hence legislators demand statutory provisions that enable their ideological allies to haul allegedly biased administrators into court. Thus American statutes and regulations are far more detailed than comparable laws in parliamentary systems (Cooter and Ginsburg 1996). The greater detail (often of a procedural nature) gives American judges sturdier handholds for reviewing and reversing administrative and regulatory decisions and hence gives interest groups of both the political Left and the political Right greater incentives to sue. Absent some unlikely constitutional revolution, therefore, parliaments in western Europe, Japan, and former British commonwealth countries are not likely to emulate American legislatures as makers of litigationinducing statutes.

At the same time, adversarial legalism is not likely to diminish substantially in the United States, even if reductions occur in some policy areas. There has been a continuing ebb and flow of adversarial legalism. The ebbs are often triggered when the inefficiencies or counterproductive effects of adversarial litigation become politically salient or when efforts are made to establish new ways of dealing with social problems. In the twentieth century, for example, bankruptcy laws and social insurance programs reduced the rate of debt collection litigation (Kagan 1984). Smaller civil suits were chan-

13. Harold Wilensky's magisterial Rich Democracies (2002) presents the most analytically and empirically sophisticated comparative analysis of governments in rich democracies. Of the 19 nations carefully studied, the United States on a variety of measures emerges as the most politically pluralistic, populist, and fragmented (the other end of the spectrum is occupied by the most corporatist and centralized democracies of northern Europe). While Wilensky also discusses points of commonality and convergence in both governmental structure and policy outputs, and emphasizes that the American differences are more of degree than of kind from other non-corporatist democracies such as Great Britain, Canada and Australia, he does put the US at one pole. And he emphasizes that the U.S remains unique, among other things, in "the heavy weight of lawyers and judges in shaping public policy and the related pattern of adversarial legalism" $(2002,687)$. 
neled into informal, inexpensive (and more hierarchical) small claims courts. Worker compensation programs were enacted to replace employee tort suits. More recently, state legislatures have imposed some restrictions on tort litigation. Congress created a federal injury fund for compensating relatives of victims of the terrorist attack on the World Trade Center and the Pentagon, in order to shield economically shaky airlines from a threatened rash of tort class actions. Congressional statutes sought to reduce repetitive postconviction litigation in death penalty cases, as well as appeals to court in immigration cases.

Yet the political demand for more adversarial legalism also seems insatiable. Through persistent legal advocacy, American workers' compensation tribunals gradually were transformed from bodies that acted on the basis of expert judgment to forums pervaded by costly and inefficient adversarial litigation (Nonet 1969). In the 1990s, state attorneys general signed contingency fee agreements with private tort lawyers to bring multi-billion-dollar class actions against tobacco companies. With Congress steadfastly refusing calls to intervene, the number of asbestos lawsuits has continued to climb astronomically, as lawyers sign up claimants who may have been exposed to asbestos but show no signs of illness but are merely fearful of getting it; the massive exposures created by these suits have propelled still more companies into bankruptcy. ${ }^{14}$ In 2002 , Congress responded to the financial scandals surrounding deceptive practices by Enron and other firms by expanding the vulnerability of corporate chief executives and financial officers to class action lawsuits.

Why do American politicians continue to encourage adversarial legalism (even while disparaging or seeking to limit it on some other fronts)? As the last chapter of AL seeks to demonstrate at greater length than can be recounted here, American interest groups and political leaders, both on the political Left and the political Right, fear the concentration of power and substitution of hierarchical controls that would be necessary to bring about large diminutions in the structures and practice of adversarial legalism. American political culture, distrustful of government and reluctant to fund it generously, has incorporated the ideological tenets of adversarial legalism. American voters resist significant restrictions on trial by jury, on citizens' rights to sue city hall (and bureaucracies at all levels of government), or on the use of courts as an alternative mode of political action. An entrepreneurial legal profession, pouring lots of money into politicians' campaign funds, presents a formidable obstacle to dismantling the rules and ideas that support adversarial legalism (Kagan 1994). For these and related reasons, adversarial

14. As of $2002,750,000$ asbestos-exposure tort claims had been filed against 8,000 defendants, and 67 defendant companies had filed for bankruptcy. The dockets continued to grow partly because entrepreneurial plaintiffs lawyers were seeking out and filing claims on behalf of workers who, although perhaps exposed to asbestos years ago, had not yet experienced symptoms of asbestos-related disease (Warren 2003a, 2003b) 
legalism surely will remain a prominent feature of the American way of law, ${ }^{15}$ and the United States, while perhaps growing somewhat less "exceptional," is likely to remain in a league of its own in that regard.

\section{Is Adversarial Legalism Really "Pervasive" in the United States?}

Referring to findings that property developers in the United States do not experience litigation as very common (Brisbin, Hunter, and Leyden 2002), Epp (2003) raises an interesting general point: Even if the United States, viewed comparatively, remains exceptional in the degree to which it relies on adversarial legalism to implement public policies and legal norms, what are we to make of the fact that in most policy realms the actual rate of litigation is relatively low? Does it mean that adversarial legalism is not "pervasive," or not the American way of law?

Any answer, I think, must begin with the reality that most of social, business, and political life is bound to proceed without legal conflict. Adversarial legalism often lurks in the background and, as David Johnson (2003) reminds us, helps shape American political and legal consciousness. But it is not the American way of life. In the United States, as elsewhere, most injuries, disputes, and grievances do not result in lawsuits (Miller and Sarat 1981; Hensler et al. 1991), nor do the vast majority of encounters with regulatory agencies, broken contracts, or incidents of medical malpractice. So the meaningful question is whether adversarial legalism is sufficiently pervasive to fairly be called the American way of law.

Earlier I noted that AL defines adversarial legalism not only as actual litigative activity but also as a deliberately constructed set of legal structures, rules, norms and incentives, that is, a "mode of implementing policy and resolving disputes." As a set of structures and rules, adversarial legalism provides channels through which citizens and organizations can challenge the policies, practices, or decisions of judges, police departments, school districts, regulatory agencies, and business corporations. These channels mat-

15. David Johnson (2003) appears to agree with this overall assessment, but argues that perhaps the most significant reason is the recurrence of scandal surrounding misconduct by governmental officials. I agree that is an important source of political support for adversarial legalism-notwithstanding Congress's decision to eliminate the office of special prosecutor in the wake of the investigation and attempted impeachment of President Clinton, which triggered numerous appeals to the courts and a political debate focused on the rule of law. Legal accountability is a major form of political accountability in the United States. Hence the politics of scandal, defined very largely in legal terms, is likely to be with us for a long time, periodically generating new, judicially enforceable legal controls on governmental officials. But more important than that as a source of adversarial legalism, I believe, is the political-cultural propensity to insist on detailed legal accountability for the ordinary implementation of governmental policies and important justice norms, even in the absence of particular scandals. The legal profession, inculcated with the values of adversarial legalism, is an important and potent group that serves as a special political watchdog in that regard. See Kagan (1994). 
ter, even if used only in some disputes. In the United States, due process rights, detailed statutes, and broad rules concerning standing to sue or appeal make a great many government decisions and omissions vulnerable to legal action. Distinctively American legal rules concerning class actions, contingency fees, pretrial discovery, and potentially large money damages sustain the world's largest and most entrepreneurial and aggressive legal profession, organized to invoke tort law against any business corporation whose products or wastes cause or arguably cause harm. Through the exclusionary rule and judicial elaboration of due process norms, adversarial legalism, expressed every day in motions to suppress evidence in criminal cases, is built into the process for determining the boundaries of police behavior. Police academies teach Supreme Court decisions concerning searches and seizures. Adversarial legalism is also built into the process of drawing electoral district lines, making accommodation for adults and school children with disabilities, devising logging plans for national forests, policing the honesty of corporate financial statements, protecting endangered species, and enforcing rights against employment discrimination. All that, it seems to me, is grounds for saying that adversarial legalism is a pervasive aspect of American law and government.

But what about adversarial legalism "in practice"? Epp's (2003) point is really about how often those structures of adversarial legalism are really used. As noted, they often lay dormant-either because the actual dispute rate in any particular context might be relatively low, or because there are alternative, cheaper ways of influencing policy and resolving disputes. So how can we determine whether adversarial legalism in practice is "pervasive." One step is to ask whether adversarial legalism as litigation is substantially more prevalent in the United States than other countries. As discussed above, almost all comparative sociolegal studies of particular policy areas say that the answer is "yes." But "more prevalent," it might be objected, doesn't necessarily mean "pervasive." The rate of shooting incidents at public schools has been a lot higher in the United States than in western Europe or Japan, but we could not say that ducking for cover from flying bullets (or shooting fellow students and teachers) is a defining characteristic of American schooling.

Yet the shooting incidents remind us that if a phenomenon is sufficiently frightening, it can have pervasive effects on social life even its rate is low. We don't know precisely how high the rate of adversarial legalism has to be to have a big impact. The threat of litigation does seem to be large enough to have major effects on decennial redrawing of electoral district lines, the formulation of regulations by American regulatory agencies, the practice of medicine, police department policies on use of guns, and the planning of new highways and factories. Because the mechanisms of adversarial legalism can be and are invoked at rates high enough to be threatening in a vast variety of governmental and business activities, I think 
it makes sense to say that adversarial legalism in practice is pervasive in the United States in the same sense as final examinations or standardized testing are pervasive-not everyone is affected every day, but it happens often enough, and is both stressful and momentous enough, to affect the consciousness and routines of many people and organizations.

Laura Beth Nielsen (1999) studied employment termination practices in a multinational corporation that claimed to have the same human relations norms and procedures in its United States and Canadian operations. In one recent year, almost $23 \%$ of "forced separations" in the U.S. operations resulted in lawsuits against the company, compared with 7\% in Canadaeven though Canada's substantive law protecting employees from arbitrary dismissal is more comprehensive than American law. The U.S. branch, officials claimed, had never lost any such case. But compared to their Canadian counterparts they consulted lawyers much more extensively, processed problem cases through more bureaucratic steps, and used probation processes less often. These differences reflected differences in legal rules and structures, such as (a) the more aggressive American plaintiffs' bar and (b) the greater unpredictability and potential magnitude of potential damage awards in the United States (due to the use of juries and the vagueness of American legal rules concerning damages).

Was the litigation rate for the American corporation "high?" It was high in relation to the Canadian branch, and $23 \%$ strikes me intuitively as high, but there is no fixed benchmark. Nielsen's study does make clear, however, that because the structures of adversarial legalism are always in place and used with at least some frequency, American adversarial legalism did indeed "pervade" the American branch's personnel practices. Other studies show that multinational corporations that do business in the United States and other economically advanced democracies experience litigation in the United States more often, even though most disputes are resolved without litigation (Kagan 2000). The multinationals also experience American litigation as more costly and threatening than litigation elsewhere and in consequence spend a lot more money on legal advice and accountability measures (making and keeping records that show that they are complying with the law) (Kagan 2000).

Based on this research, Epp (2003) might respond that it would be more accurate to say that adversarial legalism has pervasive effects in the United States than to say that it pervades American policy implementation and dispute resolution. I, however, think that both statements are true. Adversarial legalism as structures and rules pervades the governing process and legal decision-making systems of the United States, and adversarial legalism in practice occurs at a high enough rate to matter. Much dispute resolution and a great deal of corporate, governmental, and professional activity occur in (and are reshaped by) the shadow of adversarial legalism. To reiterate one of AL's metaphors that David Nelken (2003) finds too ferocious, "adversarial 
legalism shapes outcomes even if it continues to lurk in the bushes," ready to spring into action (p. 232). ${ }^{16}$

\section{ASSESSING THE CONSEQUENCES OF ADVERSARIAL LEGALISM}

Is adversarial legalism a "good thing"? Should other nations emulate the United States and foster it? Should the United States "tame" or eschew or diminish it? As David Johnson (2003) points out, at the beginning of AL I profess agnosticism on these issues, asserting that my goal in the book is primarily descriptive (How distinctive are American legal and regulatory processes? What are adversarial legalism's consequences?) and explanatory (Why is adversarial legalism especially prevalent and persistent in the United States?). Johnson is also correct, however, in noting that AL is pervaded by normative or evaluative statements. While praising adversarial legalism's responsiveness to new justice claims, I also repeatedly refer to certain aspects of "the American way of law" as "problematic," "disturbing," "inefficient," or "unjust." I express the cautious hope that AL will help the search for changes that might reduce the "adverse consequences" of adversarial legalism in the United States while preserving its virtues.

This blending of the descriptive and the normative in AL flows from the effort to describe the consequences of adversarial legalism in terms of values - such as efficiency, equality, timeliness, costliness, predictability, responsiveness, effectiveness, and justness. In doing so, AL departs from the ostensible value neutrality prized by many social scientists (even those who recognize that value neutrality is difficult to fully attain). But it comports with another significant tradition in sociolegal studies. In the 1960s, Philip Selznick (1969) urged social scientists to examine empirically the social and legal arrangements that advance or diminish the achievement of "legality."17 Law and legal institutions, he argued, can be more or less arbitrary, more or less responsive to human needs, desires, and conceptions of fairness and decency. And those variations, he continued, are important to identify and explain, for in his view, the study of the institutionalization, realization, or

16. This is the point Epp refers to when he says that AL's thesis "is not that U.S. policy processes are always or even usually subject to adversarial legal contestation . . . [but] that policy and administrative processes in the United States are widely perceived to be subject to the possibility (thus, the threat) of full-blown legal contestation and judicial oversight-and that in the relatively small proportion of disputes in which full-blown legal contestation does occur, it is more complex, adversarial, and lawyer driven than in other countries" (2003, 747). I agree-except that 1 would emphasize that the perception of legal risk, even if often exaggerated in the minds of doctors and business executives, is not unfounded. They can truly be "subject to" adversarial legalism as a matter of law, even if it happens in practice less often than they might fear.

17. For a recent examination of Selznick's work on "legality" and its influence, see Kagan, Krygier, and Winston (2002). 
frustration of such human values is not only a legitimate but a compelling purpose for empirically oriented social scientists. ${ }^{18} \mathrm{AL}$ is written in light of that conception, just as (it seems to me) are books such as Johnson's The Japanese Way of Justice and Epp's The Rights Revolution.

Not surprisingly, therefore, neither Epp (2003) nor Johnson (2003) criticizes AL for attempting to describe the consequences of adversarial legalism in value-laden terms. David Nelken (2003) does. In using criteria such as inefficiency or delay, he argues, AL errs in judging legal processes by "their outcomes," which is "excessively instrumental," and compounds the problem by employing external policy-oriented criteria rather than law's internal criteria. Law, he says, is not always intended to facilitate policy outcomes: "appeals to principle are often meant precisely to blunt calculations based on policy." To me, however, when AL describes the consequences of legal processes in terms of variables like efficiency, timeliness, costliness (which relates to accessibility and equality), fairness, and predictability, I am not referring to external criteria. Rather, these are essential, "intrinsic" aspirations of the rule of law and legal justice. In contemporary democracies, many legal scholars, government officials, lawyers, and laypeople want to know not merely whether judges reliably decide in accordance with the law but to what extent the courts are impossibly cumbersome, costly, and slow; and how their processes affect the fairness of pretrial settlements; and how responsive they are to the concerns of societal underdogs; and how they affect patterns of social, economic, and governmental life. If, as Nelken indicates, that is not the focus of European legal education, that unfortunate fact shouldn't inhibit me or anyone else from asking whether legal processes differ in the extent to which they affect outcomes. One of my motivations in writing $\mathrm{AL}$ was to go beyond the many sociolegal studies that focus only on legal processes and legal discourse and to ask what difference those variables actually make (see Kagan 1995).

The more serious concern is that AL's focus on outcomes, viewed in policy terms, leads to misleading findings. In my view, however, thinking about and describing legal processes in terms of values such as efficiency, fairness, predictability, costliness, and equity - the kinds of criteria that matter to people who must use or face a legal system-makes for better, not worse, sociolegal inquiry. I assume that sensible legal policymakers are interested not only in compliance with legal rules and the internal operations of legal institutions but also in legal processes' regulatory and second-order effects. Hence a focus on consequences can force the investigator to ask harder questions and look for a wider, not a narrower, range of affected persons, values, and data. But the key is not whether the researcher is concerned about policy or not, but in how well and how thoughtfully the re-

18. Selznick's position was sharply criticized by Black (1972), who in turn was criticized by Nonet (1976). 
search and assessment are undertaken. And in that regard, despite Nelken's general beef and the many interesting observations he offers, I fail to detect in his essay any specific examples in which the value-based criteria used in AL lead to empirical findings or overall interpretations that are incorrect or misleading. ${ }^{19}$

Johnson (2003) (like Epp) makes a different argument, that is, that AL undervalues American adversarial legalism, exaggerating its "problematic" consequences while discounting or disregarding its social and political benefits. Moreover, he argues that the book fails to make the criteria for description, and hence implicitly for evaluation, sufficiently explicit and precise. Finally, he raises interesting questions about "how the weighing [of costs and benefits] should be done," given the difficulties of counting up those costs and benefits, their incommensurability, and the kinds of things (symbolic as well as concrete) that should be taken into account.

How can we assess and compare the consequences of different modes of legal ordering? All methods of policy implementation and dispute resolution, of course, have both virtues (when they work well) and potential (or even inherent) deficiencies or vulnerabilities. Compared to adversarial legalism or expert judgment, bureaucratic legalism promises greater fidelity to legal rules, evenhandedness, and predictability, but it can yield injustice when judiciaries or bureaucracies are too poorly staffed to process cases promptly, or worse, are intimidated by a dominant political party (Ulc 1972; Muller 1991). ${ }^{20}$ As Johnson tells us, bureaucratically supervised Japanese prosecutors may be more consistent than their decentralized U.S. counterparts in dealing with everyday street crime, but they lack American prosecutors' incentives to seek fame and fortune by mounting high-visibility prosecutions of corrupt politicians and corporate executives. ${ }^{21}$ Conversely,

19. Nelken (2003) is correct, I think, that the various criteria I employ sometimes conflict. A high level of predictability, he notes, many mean a lower level of responsiveness to innovative justice claims and vice versa. Too strong a push for efficiency can undermine legal deliberation and accuracy. Legal institutions, of course, often struggle with these tradeoffs. And that, I think, should support, not negate, the legitimacy of describing legal outcome in those terms. Perhaps Nelken is correct, however, that $\mathrm{AL}$ is not always consistent and comprehensive in its assessment of particular legal processes, describing them in terms of their failure to achieve one value while neglecting their simulataneous success on another dimension.

20. Johnson (2003) points to a similar, if less horrible, tendency in Japan, where judges who decide against the interests of the ruling LDP party have seen their careers stagnate or have been transferred to less desirable assignments (Ramseyer and Rasmusen 2001). Here, as elsewhere, the absence of an aggressive and politically viable democratic opposition is a major threat to the promise of bureaucratic legalism, although it must be said that longstanding one-party dominance would likely result in a curtailment of the effectiveness of adversarial legalism as well, although perhaps not so easily.

21. On the other hand, French, German, and Spanish prosecutors and magistrates, while also professionally recruited and bureaucratically supervised, seem to have had both the independence and incentives to investigate and prosecute the powerful in the last decade. Thus I suspect the timidity Johnson observes in Japan is more attributable to particular aspects of 
compared to bureaucratic legalism, American adversarial legalism offers greater responsiveness to individual litigants or to interests that seek to change the status quo, and it creates more space for independent-minded judges, prosecutors, defense lawyers, and juries to challenge the policies of a president or an attorney general, thus erecting stronger bulwarks against tyranny. But in routine cases, adversarial legalism seems to be more costly, cumbersome and unpredictable than a reasonably well-functioning system based on bureaucratic legalism, and that is often a source of injustice.

Whether the United States (or any nation) would be well advised to rely less or rely more on adversarial legalism (in general or for a particular social problem) is a very complicated and difficult question. To refer to an example mentioned earlier, the American tort system is more inconsistent and inefficient than the Dutch welfare state in providing health care and income-replacement benefits to asbestos victims. But the U.S. tort system has more powerful tools of pretrial discovery and greater capacity to energize lawyers (by offering contingency fees, opportunities to bring class actions, and the prospect of very large damage awards). Thus it can help accomplish difficult things like compelling the Catholic Church to change its policies concerning sexual abuse by priests. How can one decide whether adversarial legalism's greater effectiveness in generating normative changes and its regulatory strengths outweigh its weakness as a mechanism for consistent and efficiently delivered compensation?

That question's difficulty arises from two problems. The first is what might be called the "information problem": identifying and counting up all the social costs and social benefits that flow from a legal practice. The second is what David Johnson refers to as the "incommensurability problem," that is, weighing a legal practice's social costs against its social benefits. In light of those problems, I assert in AL that it is impossible to determine whether, in an aggregate sense, adversarial legalism's benefits in the United States exceed its costs. The same may be true not only of whether the United States has "too much adversarial legalism" but also of whether Japan or Great Britain or Italy has "too little."

Of course, policymakers often decide important issues despite the knowledge and incommensurability problems. They commonly sidestep the paralysis induced by the ideal of "comprehensive rationality," first by approaching problems segmentally and incrementally, second by using the best available information, a dose of theory, practical reasoning, and intuition (Braybrooke and Lindblom 1970). American legislatures often avoid a choice between adversarial legalism and other modes of dispute resolution and policy implementation by devising policies that allow for a mixture of

Japanese culture and politics, rather than to inherent deficiencies in the bureaucratic legalism model. 
approaches (Mashaw 1983), or by requiring disputants to take their claims to a bureaucratic process before going to court. ${ }^{22}$ In trying to make those judgments, much depends on a variety of contextual factors peculiar to the policy domain, particularly the strengths and weaknesses of alternatives to adversarial legalism, and prospects for fixing the weaknesses.

Analogously, in AL I shy away from proposing any particular policy reforms, suggesting that is best left to experts in particular policy areas, focusing on all the specific contextual factors. And rather than trying to prove that the costs or weaknesses of adversarial legalism in particular areas of American law outweigh its benefits, I simply assert that certain practices have "problematic" or "unjust" consequences. For example, I point out, based on numerous studies, that American criminal and civil adjudication (and in civil litigation, pretrial processes) are so costly and unpredictable that they often compel disputing parties to forego legally valid claims or defenses, and probably do so more often than do more hierarchical modes of adjudication. Similarly, I demonstrate that the eruption of adversarial legalism in disputes involving economic development projects that raise environmental concerns often results in costly policy outcomes that are shaped largely by the felt need to avoid the costs and delays of adversarial litigation, regardless of the merits of the claim. My purpose in making such claims is not to argue for any specific solution, but to invite thought about directions for possible change. ${ }^{23}$

\section{Criteria/Method}

David Nelken (2003) points out that AL provides no precise definition of when American adversarial legalism is "excessive." It is true that I do not state at what point the consequences of adversarial legalism become "disturbing" or "costly" or "unjust." After all, Nelken reminds us, no legal process is costless, even (or especially) when it works well,

22. Many American state legislatures, for example, have addressed the problem of whether medical patients can immediately sue HMOs for malpractice (seeking damages for pain and suffering or even punitive damages) when they have suffered from the denial of coverage for certain procedures, or whether those patients should in the first instance have to direct their claims to a specialized administrative body, where the issues would be addressed by panels of physicians and consumer advocates (expert and political judgment) rather than by judges and juries. Some legislatures have authorized immediate lawsuits, thereby inviting increased adversarial legalism, while other legislatures have mandated initial decisions by administrative panels (Pollitz, Crowley, and Bangit 2002).

23. Despite that disclaimer in AL, Epp (at times) and Nelken (repeatedly) seem quite sure about what reforms and changes in American law and governance $\mathrm{I}$ really do desire or recommend. Perhaps that reflects a concluding chapter in which, in asking what it would take to bring about substantial reductions in adversarial legalism in the United States, I hypothesize a number of major changes in law and governance, noting that they are at least normatively plausible and worth thinking about - although I again say that they are politically highly unlikely and are not specific recommendations. 
and no system works well all the time. I don't think I have a good answer to that objection. I'm not sure there is one. Let me explain, however, how I proceeded.

One approach that I take in AL is to present a series of cautionary tales. Each provides a case history in which I presume most readers would agree, intuitively, that American adversarial legalism in practice was extremely costly and that the outcomes failed (by a lot) to meet basic normative standards of justice or produced unfortunate social consequences. For example, I discuss the Oakland Harbor case, where years of adversarial litigation in successive forums failed to prove that the dredging plans in question threatened real environmental harm. Meanwhile, the legal delays imposed such large economic and social costs on the seaport community that government officials felt compelled to agree to a succession of ever more costly ways of disposing of the dredged material. ${ }^{24}$ I discuss the litigation over the validity of the will of the heir of the Johnson and Johnson fortune. There, extraordinary litigation costs ( $\$ 25$ million) and an unpredictable mode of adjudication compelled Johnson's widow to agree to what knowledgeable legal commentators saw as a legally and morally undeserved $\$ 40$ million settlement with the Johnson children, who had been cut out of the will (apparently for good reason) but who could afford to hire a Wall Street firm to conduct a litigation blitz (Langbein 1994).

I do not claim these or the other cautionary tales are typical. Rather they serve as vehicles for analyzing why adversarial legalism occurred and had such disturbing consequences. The Oakland Harbor saga, for example, stemmed from a statutory structure that (1) greatly fragmented governmental authority, with different agencies employing different legal criteria, (2) imposed legal standards demanding extraordinarily ambitious levels of of comprehensive rationality (i.e., exhaustive analysis of numerous environmental, social, and economic consequences, (3) authorized a wide range of interest groups to challenge governmental officials in court, and (4) entailed high levels of legal unpredictability. AL goes on to show that these characteristics are not unique to the problem case. Those same four features pervade efforts to balance economic development and environmental protection in the United States-not only in harbor dredging but in regulatory rule making, highway planning, facility siting, national forest planning, and habitat preservation. The kind of legal deadlock in the Oakland Harbor case is not unusual. In many other cases, governmental and private sponsors of development projects are compelled to make large side-payments to legal objectors simply to avoid the delays of adversarial legalism, regardless of the validity (or invalidity) of the objectors' arguments. That is true even

24. For a more complete analysis of that and a subsequent case, see Busch, Kirp, and Schoenholz (1998-99), for a critical analysis of my original article on the Oakland Harbor story, and my response (Kagan 1998-99). 
if adversarial legalism (or the threat of it) often promotes socially desirable redesigns of development plans or the abandonment of ill-conceived projects.

Similarly, the kind of high litigation costs and legal unpredictability that characterized the Johnson $v$. Johnson will contest stem from the basic structures of civil litigation in the United States-a lawyer-driven pretrial discovery process, a costly and cumbersome jury trial system, a politically selected and weakly supervised judiciary, the unreviewability of jury verdicts, and so on. Thus there is abundant evidence cited in AL, some of it discussed by Joseph Sanders (2003) in this issue, that in tort cases, litigation costs consume a significant proportion of the ultimate payout, professional lawyers do a poor job of predicting outcomes, "nuisance settlements" are coinmon, many tort victims are overcompensated, and many more are undercompensated. To be sure, all formal legal processes are costly. But a process like the U.S. tort litigation system in which 40 or $50 \%$ of the amounts paid out by defendant insurance companies end up in the pockets of lawyers can hardly be called anything but woefully inefficient.

The other primary method used in AL to assess outcomes is comparison with parallel legal processes in other economically advanced democracies. For example, all legal regimes involve some level of legal uncertainty, and all formal legal processes are slower and more costly (and hence are unequally inaccessible) than informal dispute resolution methods. But AL seeks to show that American adversarial legalism is especially costly, inaccessible, unpredictable, and so on. That judgment is based on studies that compare how the United States and at least one other economically advanced democracy deal with a particular problem-adjudicating criminal cases, regulating nursing homes, collecting debts, issuing air pollution permits, and so on. Often, as noted earlier, the comparative case studies indicate that the other country's method is more efficient, predictable, or reliable than American adversarial legalism. ${ }^{25}$

Of course, American legal and regulatory regimes are unpredictable only in a relative sense. Lawyers often can give clear advice as to likely legal consequences, and in most circumstances individuals and business firms have a good sense of what their rights and obligations are without consulting lawyers. Many, perhaps most, legal disputes are resolved relatively quickly and relatively fairly without too much expense. The point is that American legal regimes and processes, according to the comparative studies, entail higher levels of legal uncertainty, higher costs, and more compulsion to

25. To show that the American side of the comparative study is reasonably representative, I generally go on in AL to show, based on other purely domestic studies, that the characteristics of the particular sphere of American regulation, policy implementation, or adjudication described in the comparative study are not unique to that particular case. 
compromise legally meritorious claims and defenses to avoid the costs, delays, and uncertainties of litigation. ${ }^{26}$

\section{The Risks of Selection Bias}

Johnson, Epp, and Nelken (all 2003) all suggest that AL is misleading because the comparative studies I rely on either exaggerate the virtues of other countries' methods or overlook their deficiencies. For example, AL discusses a closely observed comparison of misdemeanor courts in United States and London by Graham Hughes (1984); he reports that in the London court defendants participated more fully, obtained a more attentive hearing from the judge, and generally were treated in a more orderly, dignified fashion. AL is misleading in that regard, according to Epp, because it does not take into account certain criticisms of Magistrates' Courts by British scholars. ${ }^{27}$ Similarly, Johnson implies that AL's reliance on the Aoki and Cioffi study of solid waste disposal regulation in Japanese and American factories is misleading because it ignores other policy areas in which Japanese regulation is "too cooperative" and ineffective. In AL, drawing on comparative analyses of French, German, Japanese, and Dutch practices, I suggest that more hierarchical systems for recruiting and supervising police and prosecutors might be worth exploring in the United States. But hierarchical control, according to Epp, would look less attractive had I discussed certain studies of British efforts (beginning in 1984 and 1985) to improve their rather decentralized criminal prosecution system by adding nationwide hierarchical controls-since those reforms have been

26. Nelken (2003) suggests that the comparisons are not apt because the American legal system is more ambitious in its reach than those of western Europe, its courts entertain a wider range of claims, its place in political and legal life somewhat different. But the comparative studies I present are real comparisons-regulating disposal of hazardous wastes in the U.S. and Japan, compensating asbestos victims in the U.S. and The Netherlands, plea bargaining in the United States and Germany, permitting garbage dumps in the U.S. and England, regulating nursing homes in the United States and Australia. The legal systems of both countries really were called on to do the same thing, to achieve very similar substantive goals.

27. Epp does not dispute the accuracy of Hughes's account of the London magistrate's court. It remains persuasive, I think, even if British scholars have criticized other magistrates' courts staffed by lay rather than professional magistrates-a criticism that AL mentions, citing the same sources that Epp does (p. 265 n. 29). Moreover, AL explicitly says "Hughes was by no means an unqualified admirer of the English system, and his comparison, focusing on two courts at a particular moment in time, may not be fully representative" (p. 90). But while Epp emphasizes that acquittal rates in magistrates courts are lower than in Crown Courts with jury trials, in AL I noted they are about the same as acquittal rates in American jury trials. Moreover, penalties in magistrates' courts are much milder than in American courts, and unlike the United States, there is little evidence that defendants who insist on a magistrate's trial and are convicted are punished more harshly than those who plead guilty (Darbyshire 1997a, 1997b). 
disappointing in eliminating the problems the new controls were supposed to solve. ${ }^{28}$

I willingly confess that I haven't read all the available research and commentary on the French, German, Japanese, Dutch, and British legal systems; I surely missed studies that are critical of those systems. ${ }^{29}$ More information of that kind would indeed have enriched AL. On the other hand, I think I did read most relevant comparative sociolegal studies. And most of them indicated that the parallel American processes tend to be more adversarial, complex, punitive, costly, and legally uncertain. But one way of reading Epp, Johnson and Nelken is that there may be a kind of selection bias in that body of comparative studies. That is, perhaps comparative sociolegal scholars, imbued with an antihegemonic spirit (or simply looking around the world for good ideas), are particularly drawn to specific comparative studies in which the American practice seems more problematic. ${ }^{30}$ (What politically liberal U.S. scholar wants to be accused of American triumphalism?) As noted, by relying on focused sociolegal comparisons, I consciously sought to avoid Nelken's and Epp's charge that I compared the U.S. system, flaws and all, with idealized (rather than empirically accurate) descriptions of other countries' processes. ${ }^{31}$ But if there really was selection

28. I find myself wondering whether the British reforms actually "failed" (as the British authors Epp cites put it) or merely fell substantially short of complete success. It is hard to know whether the British efforts to retrain and restrain local police have been less or more effective than the American effort to accomplish similar objectives through U.S. Supreme Court decisions which seek to impose ideals of civility and accuracy on an inherently difficultto-regulate set of law enforcement bodies by means of defense-lawyer-activated adversarial legalism. This is where we need the truly comparative studies that Nelken points out we lack.

I would also note that Great Britain does not provide the best example of the potentials and limits of a hierarchically structured system for holding police to legal standards. The British stab at centralized supervision of police and prosecutors has been relatively recent (the statutes Epp cites were enacted in 1984 and 1985), compared to the long-standing hierarchical approach to professionalizion and supervision employed by countries such as France, Germany, and The Netherlands (AL, p. 72 and studies cited there).

29. This was not a result of the "self-imposed refusal" that Nelken attributes to me, but the product of limited time and energy (a term I prefer to laziness) and, more fundamentally, to my sense that given the thrust of AL, I did not have to produce a comprehensive assessment of each and every legal system for which I discussed a particular part.

30. David Nelken asserts that AL "relies heavily on American scholars who have researched abroad," and he suggests that they may have been especially interested in learning "whether other systems are any better than theirs." On the other hand, 13 of the 34 comparative studies listed on table 1 of AL are by non-American scholars, and in the course of the volume I discuss works by other non-Americans. I, for one, don't detect any higher or lower level of "anti-American bias" in one group rather than the other.

31. Nelken does not support his concerns by explicitly refuting any of the many comparative studies (or studies of one European country's process) cited in $\mathrm{AL}$, and Epp offers explicit criticisms of only two-Langbein (1985) on German criminal courts and Pizzi (1998) on European versus American criminal trials. Yet AL cites a number of experts on the German criminal process (Weigend 1980; Frase and Weigend 1995; Hermann 1992; Machura, 2000) who generally confirm Langbein's analysis, as well as careful studies of the French (Frase 1990) and Dutch (Peters 1992) systems that support Pizzi's analysis. Most of the studies I used in AL struck me as careful and plausible, and it would take more than vague doubts to persuade me otherwise. 
bias, the comparative studies that I found and then discussed in $A L$, while accurate in themselves, may not be fully representative of the other countries' legal processes. This, at least, is what Epp, Johnson, and Nelken seem to think, and conceivably they are right. If they are, then AL may make the approaches of other countries look somewhat "too good."

That failing in AL would matter more, however, if I had sought to show that the legal systems of other democracies, taken as a whole, are superior to the American system. But in AL I say clearly that I regard such global comparisons as impossible to do in an intellectually defensible manner-partly because the comparative sociolegal literature is not yet comprehensive and rich enough, and partly because reading everything in English about each country mentioned seemed impossible. Although more comparative information surely would have been better, I don't think AL's insights about a particular American process based on a focused comparative case study are invalid. Suppose I compare a school lunch in a typical Chicago third grade with a typical school lunch in Paris, indicating that the French lunch was nutritionally better, less expensive, and tastier. The insight for Americans would still hold, I think, even if the Parisian school in question was actually not typical but better than average for Paris or for France as a whole.

In $\mathrm{AL}$, for example, I discuss two classic articles by John Langbein $(1979,1985)$, a leading comparative legal scholar, that indicate that both the criminal court process and civil litigation in Germany are far less costly, more efficient in many ways, ${ }^{32}$ and allow many more criminal defendants and civil litigants to have their say in open court than the parallel processes in U.S. courts. AL relies on a study by Hanf and Smits (1991) of the Rotterdam harbor that parallels my own study of the effort to dredge Oakland Harbor in the late 1980s and early 1990s; Hanf and Smit show that The Netherlands, employing a pluralistic and participatory but nonlegalistic process, solved a much larger and much more environmentally hazardous harbor dredging problem without the repetitive, delaying litigation and the adverse economic effects that stemmed form American adversarial legalism. ${ }^{33} \mathrm{AL}$ relies on Braithwaite's (1993) comparative study of nursing home regulation

32. Nelken suggests that it misleading to show that trials are shorter in some European nations, since important and difficult disputes are much less often routed through the courts there. But the comparison is quite relevant, I think, because only a small proportion of cases in U.S. courts (even if much larger than in Europe) are "important and difficult."

33. Even if Rotterdam dealt with harbor dredging more effectively than Oakland, Nelken suggests that the Dutch corporatist approach to conflict-that is, too little adversarial legalism-also led to the waste of millions of public dollars invested in the declining shipbuilding industry. Perhaps so, but that example, it seems to me, is beside the point, for the subsidy issue was a wholly political one, akin to the U.S. government policies that subsidize the American sugar industry. Adversarial legalism cannot prevent the sugar subsidy, and a more adversarial and legalistic legal system in The Netherlands would not have ended the shipbuilding subsidies. Here, as in various other points, Nelken's critique confuses legal and political or cultural variables. 
to show that the regulatory process in the United States is more legalistic and divisive than in Australia and hence less successful in preventing terrible care. AL relies on a study by Lyle Scruggs (1999) that shows that despite its higher level of legalistic enforcement, the United States lagged behind most other OECD countries in the 1980s in the rate of reduction of sulphur dioxide and nitrous oxides in the air, in proportions of municipal wastes that are recycled, and reduction in pesticide use in agriculture. As noted earlier, AL uses Vinke and Wilthagen 1992) to point out that in The Netherlands, in contrast to the U.S., victims of asbestosis routinely obtain ongoing coverage of medical costs and prompt, moderate compensation via an administrative process-without having to pay large sums to lawyers and without bankrupting dozens of companies.

In each of these case studies, the differences in outcomes flowed from the less adversarial and legalistic, more hierarchical way in which the other country organized its processes. It seems to me we learn a lot about the consequences of adversarial legalism from that kind of comparison, even if there are some other areas of law and regulation in which one might discover that the U.S. approach is more efficient and effective than the parallel process in Germany, Australia, or The Netherlands-or even if, as Nelken says, the German adjudicatory system is one of the most efficient in Europe and hence not representative of bureaucratic legalism more generally. The analysis in AL is misleading, therefore, only to the extent that either the author or the reader generalizes too far from the focused comparisons. Speaking for the author, I tried to avoid that trap, while acknowledging that at times, particularly in summary passages, I can be read has having fallen into it.

The problem is hard to avoid. Any comparison based on a limited number of case studies, like AL, necessarily shines a light on only a few slices of each nation's legal processes, and the remaining darkness may obscure very different legal phenomena. The alternative, however, is full-scale comprehensive comparative analysis of all or many aspects of both nations' legal systems - a task that in its magnitude is likely to induce scholarly paralysis.

\section{On Emphasizing Adversarial Legalism's Adverse Consequences}

David Johnson (2003) complains that AL is misleading in another way - that it pays too little attention to the positive features of American adversarial legalism, focusing too heavily on its more disturbing consequences. It is indeed true that AL tells many more stories about American legal processes that frustrate the search for justice than stories that demonstrate its positive achievements. Hence Johnson is arguably correct in suggesting that $\mathrm{AL}$ may not provide a balanced portrait of the American way of law. 
AL frequently offers a two cheers (or sometimes only one) for adversarial legalism. I observe that compared to other legal methods, adversarial legalism makes courts and public policy more responsive to the claims of those who challenge the arbitrary exercise of governmental and corporate power or who seek to advance new normative standards. One of the book's final paragraphs also asserts:

American adversarial legalism is far from the worst of all methods of law and governance. In some respects, and at some moments, it is the best. By dispersing power and emphasizing judicial independence, adversarial legalism may provide stronger barriers against the tyranny of ideologically extreme governments, either of the Left or of the Right, than those erected by hierarchically organized legal institutions. (Pp. 251-52)

I also indicate that if adversarial legalism were by some miracle to be drastically eliminated in the United States, without also instituting major changes in other aspects of American law and public administration, then injustice almost surely would grow. Adversarial legalism fills a void in American governance. In a structurally fragmented, deadlock-prone, and often underfunded governmental system, adversarial legalism provides an essential way of elaborating and enforcing important norms of due process, equal treatment, and protection from harm. The United States lacks the highly professional, hierarchically supervised national bureaucracies, social welfare systems, and corporatist arrangements that characterize western European governments. In their place, aggressive lawyers and a powerful judiciary play an important role in imposing accountability on far-flung government agencies, law enforcement bodies, and business corporations.

Yet AL does expend more energy in discussing why it is difficult to add the third cheer, explaining that choice as follows:

Why emphasize the Oakland dredging story [a tale of deadlock-producing, social-welfare-diminishing adversarial legalism] rather than the $\mathrm{Al}$ abama [successful, welfare-enhancing] prison-reform litigation? Why focus on adversarial legalism's dark shadow rather than on its luminous successes? Indeed, why concentrate on the extreme cases that lie within either tail of the distribution, rather than on the American legal system's more typical cases? One reason is that in institutional analysis, as in medicine, pathological cases have diagnostic value, revealing fundamental systemic mechanisms. If we understand the reasons for the adverse effects of legal institutions and practices, they perhaps can be altered for the better. Second, the pathologies of adversarial legalism are of immense social importance, for they are both unpredictable and enormously debilitating. They engender costly "defensive medicine," deter the assertion of just claims and defenses, distort and delay the 
implementation of governmental programs, undermine faith in the justice system, and invite political overreaction. If we are to retain the system's virtues, it is important to understand and hence to tame its vices. (Pp. 32-33)

To be sure, AL would have provided a more balanced portrait had I devoted substantial attention, for example, to the role of adversarial legalism in entrenching and expanding constitutional protections for freedom of expression and religion; in establishing and defending women's access to safe abortions; in providing investors and entrepreneurs greater security against governmental favoritism, unfair competition, and judicial bias; in sharply reducing the historic malapportionment of American state legislatures; in delegitimating racial and gender discrimination; and so on. But that would have made for a much longer book, and also one that while more holistically descriptive would have been less pointed, less focused on the analytic objective quoted above.

Johnson is not merely suggesting that I should have written a somewhat different book, however. His more fundamental critique is that AL's emphasis on the "adverse effects" evokes a misleading assessment of adversarial legalism. Neither Johnson or the other reviewers claim that AL's portrait of the problematic consequences of adversarial legalism (which takes up a very substantial part of the book) is inaccurate. But by referring to instances in which Japanese law and governance do not work very well, Johnson suggests that adversarial legalism is a lot better than the impression conveyed by my account. For example, in AL I discuss Aoki and Cioff's (2000) finding that the legalistically enforced American RCRA ${ }^{34}$ regime for collecting and disposing of industrial waste was less effective than the more cooperative Japanese regulatory regime in inducing a multinational corporation to institutionalize regulatory norms. But wait a minute, Johnson warns. The cooperative Japanese regulatory style has its own downside, as illustrated by his account of ineffective Japanese regulation of financial institutions and tobacco use and marketing. Thus, Johnson argues, "the benefits of the American way of law look especially attractive to persons who do not enjoy them," and elsewhere he says that the social costs of American adversarial legalism "pale in comparison to the costs of the more 'cooperative' Japanese approach."

Johnson is correct in suggesting that a legal or regulatory system might be very problematic if it does not have enough adversariness or enough legal formality. Perhaps I do not make that point strongly enough in AL. ${ }^{35}$ Yet

34. RCRA stands for the federal Resource Conservation and Recovery Act, codified at 42 U.S.C. $\$ \S 6924$ and 6928.

35. I do discuss the U.S. Supreme Court's "due process revolution" of the $1960 \mathrm{~s}$ as a response to the insufficient level of adversarial legalism in communities where indigent defendants were not entitled to free legal counsel and police were poorly supervised. 
I know of no way to estimate the net cost-benefit ratio of American regulation compared to Japanese regulation, taken as a whole. The evidence is clear that Japan's nonlegalistic, corporatist approach to regulation has been ineffective in some sectors or programs (Gelb 2000; Milhaupt and Miller 2000; Kagan 2000). Hierarchical legal and regulatory institutions, like adversarial legalism, can work well or can work poorly. And so the cases of Japanese regulation that Johnson discusses do not refute the case studies suggesting that in some contexts and programs, Japanese cooperative regulatory methods get results equal to or better than American adversarial legalism. ${ }^{36}$

Moreover, the weaknesses in Japanese law that Johnson discusses do not refute AL's suggestion that some modification of American regulatory methods, by increasing levels of business-government cooperation, might increase regulatory effectiveness. "Less adversarial legalism" in the United States does not mean a radical swing to the highly informal, corporatist mode of regulation that has characterized Japanese financial services regulation. And to cure the pathologies of Japanese cooperative regulation (perhaps the most cooperative in the world), Japan need not adopt full-blown American-style regulatory methods, the most adversarial and legalistic in the world. There are lots of alternative points in between.

Consider again figure 1 above and imagine Japanese regulation occupying the point designated Nation $\mathrm{X}^{1}$. There is such large gap between Japanese and American regulatory style that Japan could swallow a substantial dose of adversarial legalism, moving to point $\mathrm{X}^{2}$ (which might well be a good thing $)^{37}$ and still have far less than the United States. Conversely, as I argue in AL, the United States could cut back a bit on adversarial legalism and still be far from the Japanese norm. Both U.S $S^{1}$ and Japan ${ }^{1}$ have their own pathologies. The optimal point, according many regulatory scholars, is not "all cooperation all the time" versus all-out adversarial legalism, but a judicious blend of both approaches (Ayres and Braithwaite 1992; Scholz 1984; Coglianese and Nash 2001; Bardach and Kagan 2002).

Similarly, Johnson says that AL's critique of plea bargaining in the United States (as induced by the high costs and unpredictability of adversarial legalism) paints too dark a picture of the American system, arguing that Japanese methods of obtaining confessions are worse. But why is Japan's criminal justice system, which is notable for the infrequency of effective

36. In addition to Aoki and Cioffi (2000) see Aoki, Kagan, and Axelrad 2000; Wallace 1995; Wokutch 1992 (worker safety regulation). In addition, the conventional wisdom is that Japanese regulations concerning energy conservation are far more effective than such efforts in the United States.

37. I have argued that Japan could inject more adversarial legalism into its criminal justice process, which probably would be quite desirable, without worrying that they would ever replicate the kind of adversarial legalism that characterizes the American criminal justice process (Kagan 2002). 
adversarial challenge (Feeley and Miyazawa 2002), the proper benchmark? As implied by figure 1 , there are other points on the continuum between American adversarial legalism and Japan's criminal justice system. The weaknesses in Japan's hierarchical system does not mean that adversarial legalism is preferable to all hierarchical criminal justice systems or that the American criminal justice system cannot be usefully compared, as AL does, to systems like Germany's, which seem to avoid some of the pathologies of Japan's (Langbein 1985; Frase and Weigend 1995). ${ }^{38}$ In sum, although Johnson properly points out that too little adversarialism can be a bad thing (and AL perhaps should have made that point more strongly), that does not mean that AL was incorrect or biased in arguing that adversarial legalism often has adverse effects in the United States.

Perhaps Johnson's point could be restated. As AL says:

[T]he mechanisms of American adversarial legalism-the very kinds of mechanisms that sometimes block environmentally obtuse development projects, that yielded Brown $\vartheta$. Board of Education and the prison reform decisions, and that sometimes free the unjustly accused-produce irrational, unjust, and inefficient outcomes as well. (P. 31)

If one can't diminish adversarial legalism without deeply impairing its capacity to achieve positive results-an argument that Nelken (2003) makes, but which I question - then AL's emphasis on the adverse consequences is arguably misleading, making AL overall look worse than it really is. But since AL frequently mentions and sometimes illustrates adversarial legalism's bright achievements, I don't see why elaborating its dark side as well obscures its virtues.

38. Johnson (2003) also refers to Japan's well-known weakness in regulating tobacco (Levin 1997), implying that reflects a deficiency of adversarial legalism in that country, while the better U.S. record in tobacco control is somehow related to adversarial legalism. But many countries, without any significant contribution from litigation, have been more aggressive than Japan in tobacco control, enacting tougher regulations concerning warning labels on cigarette packages, restricting advertising, and raising taxes to use-discouraging levels. The weak Japanese tobacco control record stems not from legal variables but from the intimate political and financial links between the Japanese government and Japanese tobacco producers (Levin 1997). And in the United States, the decline of smoking rates began and continued long before antitobacco litigators began to have some successes in the late 1990s (Kagan and Nelson 2001). Direct government regulation, surgeon generals' reports, and taxation have been more important in the downward trend in American smoking rates (Rabin and Sugarman 2001; Derthick 2002). More recently, I would acknowledge, adversarial legalism has had some effects. In the mid-1990s, litigation helped unearth tobacco company documents that were widely used in the demonization of tobacco companies, which helped change the political climate. The settlement of the state attorney generals' class actions at the end of the $1990 \mathrm{~s}$ led to some increase in cigarette prices, further restrictions on tobacco advertising, and some increase in funding for antitobacco advertising-although state governments have appropriated most of the massive settlement payments for public purposes wholly unrelated to tobacco control (Rabin 2001; Derthick 2002; Kagan and Nelson 2001). 


\section{EXPLAINING ADVERSARIAL LEGALISM}

How can we explain differences in legal systems? Here again the task is complex because legal systems are such sprawling, variegated phenomena. They are like cities, where different sections and buildings have been constructed at different times, where demolition and new construction have periodically affected every neighborhood, but at different rates. And like cities, legal systems are molded by many factors in the society around them, while often playing a role in reshaping the society itself-to the extent that some scholars think it old fashioned to speak of a "law" and "society" as separate variables. Legal systems can be shaped and reshaped by religion, revolution, conquest, economics, politics, demographics, and popular culture. They are shaped by legal elites and changing legal ideas. Any explanation based on a single variable, or a small set of variables, is likely to be too simplistic. Any explanation that seeks to take many causal factors into account risks being too complicated to make much of a theoretical contribution.

AL's explanation for the relative prevalence of adversarial legalism in the United States leans toward the complicated. It gives pride of place to political culture and political structure. But it recognizes that both a nation's economic structure and its "elite legal culture"-that is, the attitudes and related actions of the American legal academy and legal profession-have a significant influence as well. To quote from chapter 3, The Political Construction of Adversarial Legalism:

In the last half of the 20th Century, all economically advanced democracies have experienced political demands for governmental action to enhance economic security, promote equal opportunity, provide for the injured, reduce the risk of harm, protect the natural environment, and safeguard human rights. The United States is unique, however, in the extent to which the governmental response has resulted in increased levels of adversarial legalism. The fundamental reason ... lies in the collision between demands for more active government and some enduring features of the American political system-political structures that fragment governmental power, a political culture that mistrusts "big government," an increasingly competitive but disaggregated business system, and a legal culture that promotes and validates adversarial legalism. The catalytic reaction of these seemingly incompatible progovernmental and antigovernmental elements has produced an approach to governance that is active but decentralized, legally constrained, and litigious. Political and economic factions, fearing that their adversaries will have too much influence on federal bureaucracies and local governments, have insisted that regulatory and law-enforcement agencies, as well as large corporations, should be held accountable via detailed laws and procedures, lawsuits, and courts. In addition, an entrepreneurial, politically active legal profession, professoriat, and ju- 
diciary all have promoted the desirability of adversarial legalism as a response to policy problems and injury compensation, successfully foreclosing attempts to seriously curtail the powers of judges, lawyers, and juries in governance and dispute resolution. (P. 58)

Professor Epp sees a contradiction in this causal story; "On the one hand, the fragmented, bureaucratically weak American state leads reformers to pursue adversarial legal reforms, while on the other, adversarial legal blinders keep American reformers from pursuing centralized bureaucratic reforms" $(2003,000)$. I don't see the contradiction. I argue in AL that the fragmented structures of American government (combined with political demands for governmental action) give policy advocates strong incentives to entrench policies in detailed statutes (or judicial precedents) that their allies can readily enforce in court against recalcitrant governmental bodies (local, state and federal) and against business corporations. Political opponents seek to build justiciable legal defenses into those same statutes and legal doctrines. At the same time, for lawyers, interest group advocates, and policymakers alike, the repeated experience of employing adversarial legalism as a mode of policy implementation and dispute resolution makes the pursuit of litigation-encouraging statutes and precedents seem both inevitable and normatively appropriate. This is the very "constitutive' function of law that Johnson suggests that I should have paid more attention to in AL.

Let me provide an example. The administration of a Republican president, George H. Bush, avidly criticized American litigiousness. But that administration sponsored the 1990 Americans with Disabilities Act-a law that accorded a large role to private lawsuits, as opposed to bureaucratic regulation, in elaborating and enforcing its basic norms (Burke 2002). There, as in the case of the landmark 1974 federal law mandating public schooling for children with disabilities (Melnick 1995), legal reformers, long accustomed to litigation as a weapon against recalcitrant schools and employers, believed in the paramount importance of judicially enforceable rights and they lobbied hard for litigation-facilitating statutory language. But they also had strong political incentives to seek a federal statute enforceable via adversarial legalism. Those incentives arose from (a) the fragmented structure of American government (thousands of local school districts, millions of separate employers) and (b) a political culture resistant to concentrated central governmental authority. Even for the Bush administration, enforcement of disability rights by lawsuit was preferable to the creation of a large and powerful new federal bureaucracy to implement of policies favoring the handicapped. For similar reasons, there was not much political support in the United States for the federal government to take primary responsibility for funding of "special education" or for expanding government subsidies for employers of disabled persons-although these are the primary policy tools for aiding children and workers with disabilities in many welfare states 
in western Europe. Those political differences-and the experiences and beliefs that flow from them-help explain why American advocates for people with disabilities emphasized a rights-and-litigation based strategy, while European advocates have generally emphasized governmentally funded benefit programs, in which litigation is quite rare. ${ }^{39}$

\section{Is Adversarial Legalism Democratic?}

Relatedly, Nelken (2003) asks, "Is adversarial legalism more a consequence of the opportunities people are offered than a result of what they want from law?" AL doesn't assign precise weights to these two causal pathways. In the most immediate sense, of course, disputants respond to what is offered by legal and political elites, that is, to the incentives that stem from existing laws. From this standpoint, adversarial legalism in practice is common in the United States because (a) American politicians and judges have established and maintained the legal rules and institutions that I have called the structures of adversarial legalism, and (b) lawyers and scholars propagate the idea that asserting one's interests through litigation is legitimate and sensible.

But why have American lawmakers established those structures of adversarial legalism? In other economically advanced democracies, lawmakers have not emphasized that course. In the United States, it seems to me that popular demand-as manifested in the broader political culture-has been crucial. In Japan, Sanders (2003) tells us, Japanese social and political values strongly support governmental policies that disfavor litigation in courts and that provide alternative, more informal modes of dispute resolution. That is, culture supports certain governmental and legal structures, and the latter reinforce the former. The same, he argues, applies in the United States.

Nelken speculates that in the United States, as compared to western Europe, public demand is more important in shaping legal institutions, rules, and processes. I agree. The pathways of greater popular influence on the legal system in the United States are rooted in the fragmentation of political

39. Epp observes that the first main explanatory chapter in $\mathrm{AL}$ gives pride of place to fragmented government as a causal factor, relegating the attitudes of legal elites to a secondary role, but that the last chapter, in imagining the kinds of changes that would result in significant declines in adversarial legalism in the United States, emphasizes "cultural attitudes that celebrate adversarial-legal checks on authority." That is an interesting point, but it doesn't reflect any change of heart or contradiction. In imagining possible change, it seemed to me somewhat more likely that legal and political elites could learn to experiment with less adversarial and legalistic methods and undertake some changes in administrative law and social insurance than to undertake the huge constitutional changes that would be required to significantly reduce the fragmentation of governmental authority in the United States. Hence I focused on the former precisely because I saw the structural features of American government, and the broader set of attitudes embodied in American political culture, as the more fundamental factors in encouraging and entrenching adversarial legalism. 
authority mentioned above. Among economically advanced democracies, the United States is unique in the extent to which judges and prosecutors and top regulatory agency officials are selected in partisan political ways. It is unique in the frequency of elections. The fragmentation of political authority makes the United States unique in the extent to which individual politicians must seek support from interest groups for campaign funds and the mobilization of voters, and in the extent to which party leaders must gain the support of "back benchers" and legislative subcommittee heads to get legislation passed-and that makes the American lawmaking process especially penetrable by interest groups.

One consequence is that American legislatures and judiciaries are probably more responsive to interest group and public opinion, less dominated by government bureaucrats and committees of legal experts. To James $Q$. Wilson (1997) a major reason American criminal sanctions are much harsher than those in Great Britain-and I would add, all of western Europe-is that the lawmaking process in the United States is more open to popular pressures and sentiments. Interest groups, both Left and Right, lobby hard for provisions in statutes that make it easier for their constituents to fight for their interests in court. American appellate court judges, often reaching office after a career of political activism or holding office, are more likely than the professionally selected, bureaucratically trained judges of most other countries to see themselves not merely as legal technicians but as social problem-solvers. That is why their political ideology matters: in tough cases, Democratic judges tend to decide differently from Republican judges (Gottschall 1986; Segal and Spaeth 1993; Scherer 2001).

Returning to Nelken's question and Sanders's emphasis on the mutually reinforcing interplay of culture and legal structure, one might be tempted to conclude that, since the American political system selects lawmakers and judges who are expected be politically responsive, the structures of adversarial legalism they create and "offer" the public are likely to reflect what the public (or substantial constituencies within it) wants. But the linkage between popular opinion and adversarial legalism is far from perfect. Both popular opinion and political parties are sharply divided on numerous legal issues. And there are familiar collective action problems: courts, legislatures, and regulatory agencies can be disproportionately influenced by intensely focused groups (from trial lawyers to ranchers) with views that do not command broad popular support. Sanders reminds us that the ethos of individual responsibility that many Americans adhere to seems at odds with a good deal of American tort law and many individual manifestations of adversarial legalism. In direct opposition to the state attorney generals' massive class action suits against tobacco companies (and the resulting $\$ 240$ billion dollar settlement), a solid majority of Americans, when asked who should be held responsible for the costs of illness due to smoking, say that the individual smokers, not the tobacco companies, were at fault (Kagan and Nelson 2001). 
Even the educated public remains ignorant of or indifferent, by and large, to the intense inside battles over the pretrial discovery rules or class action provisions of the Federal Rules of Civil Procedure (Marcus 2002), although the outcomes affect the character and prevalence of adversarial legalism.

An interesting and little-researched question therefore arises: what is the relationship between American public opinion and the particular legal rules, decisions, and practices that foster adversarial legalism? Researchers have identified significant gaps between the views of the mass public and those of liberal legal elites concerning some basic Supreme Court doctrines concerning legal protection for proponents of unpopular beliefs and for criminal suspects' rights (McClosky and Brill 1983). I wonder what the findings would be if focus groups were presented with alternative arguments and asked their opinion about a variety of the rules and processes that encourage adversarial legalism. I am not at all suggesting that public opinion polls should govern the answers to such legal questions, any more than they should determine the contours of constitutional rights. Rather, I am suggesting that it would be interesting to try to answer Nelken's question about to the extent to which the American public, in getting a society pervaded by adversarial legalism, is getting what it demands or only what it is offered by legal elites. ${ }^{40}$

I suspect that a kind of prisoners' dilemma is at work. Many liberals and many conservatives would prefer less adversarial and legalistic modes of policy implementation and dispute resolution but fear that any "replacement institutions," more hierarchical in character, would be dominated by their ideological opponents. Liberals prefer liberal judges but fear a judiciary dominated by conservatives. Conservatives' attitudes are the mirror image. Thus neither are willing to try to change an inefficient system in which key adjudicative issues are tried before amateur jurors. Liberals don't like the tort system's woeful undercompensation of accident victims, and conservatives don't like the overcompensation that emerges from the same system, but liberals fear that a no-fault, publicly funded accident compensation system will be dominated by conservatives, and conservatives fear the opposite.

40. Such an inquiry might be responsive to Nelken's complaint that that AL does not make a systematic contribution to the comparative study of "legal culture." While I do not regard AL primarily as a comparative study of legal culture, I do refer to what Lawrence Friedman $(1975,223)$ calls "internal legal culture" - the ideas and attitudes of lawyers, judges, law professors-as one of several explanatory factors. But it would indeed be useful to have more systematic comparisons of mass legal cultures across countries, particularly with regard to attitudes toward the institutions of adversarial legalism or toward litigation. With respect to the latter, Hamilton and Sanders's work (1992) on popular attitudes in the United States and Japan is an outstanding example, and I also admire Kritzer's (1991) study of attitudes toward blame and claiming among accident victims in the United States and the United Kingdom. Both suggest that Americans are more likely to have litigious attitudes-although those attitudes appear to be influenced by the much greater incentives and opportunities to litigate created by the structures of adversarial legalism. 
In these and other ways, adversarial legalism may be only reluctantly the American way of law.

\section{REFERENCES}

Aoki, Kazumasu, and John Cioffi. 2000. Poles Apart: Industrial Waste Management Regulation and Enforcement in the United States and Japan. In Kagan and Axelrad 2000.

Aoki, Kazumasu, Robert A. Kagan, and Lee Axelrad. 2000. Industrial Effluent Control in the United States and Japan. In Kagan and Axelrad 2000.

Atiyah, P. S., and Robert S. Summers. 1987. Form and Substance in Anglo-American Law: A Comparative Study of Legal Reasoning, Legal Theory, and Legal Institutions. Oxford, England: Clarendon Press.

Axelrad, Lee. 2000. Investigation and Remediation of Contaminated Manufacturing Sites in the United States, the United Kingdom, and the Netherlands. In Kagan and Axelrad 2000.

Ayres, Ian, and John Braithwaite. 1992. Responsive Regulation. New York: Oxford University Press.

Badaracco, Joseph L. 1985. Loading the Dice: A Five Country Study of Vinyl Chloride Regulation. Boston: Harvard Business School Press.

Bardach, Eugene, and Robert A. Kagan. 2002. Going by the Book: The Problem of Regulatory Unreasonableness. 2d ed. New Brunswick, N.J.: Transaction Books. Original edition, Phildelphia: Temple University Press, 1982.

Black, Donald J. 1972. The Boundaries of Legal Sociology. Yale Law Journal 81:10861100.

Blankenburg, Erhard. 1994. The Infrastructure for Avoiding Civil Litigation: Comparing Cultures of Legal Behavior in the Netherlands and West Germany. Law and Society Review 28:789-808.

Bogart, W. A. 2002. Consequences: The Impact of Law and Its Complexity. Toronto: University of Toronto Press.

Boyle, Elizabeth Heger. 1998. Political Frames and Legal Activity: The Case of Nuclear Power in Four Countries. Law and Society Review 32:141-74.

Bradley, Craig. 1993. The Failure of the Criminal Procedure Revolution. Philadelphia: Pennsylvania University Press.

Braithwaite, John. 1993. The Nursing Home Industry. In Beyond the Law: Crime in Complex Organizations, ed. Michael Tonry and Albert J. Reiss Jr. Chicago: University of Chicago Press.

Braybrooke, David, and Charles E. Lindblom. 1970. A Strategy of Decision. New York: Free Press/MacMillan.

Brickman, Ronald, Sheila Jasanoff, and Thomas Ilgen. 1985. Controlling Chemicals: The Politics of Regulation in Europe and the United States. Ithaca, N.Y.: Cornell University Press.

Brisbin, Richard A., Jr., Susan Hunter, and Kevin Leyden. 2002. Adversarial Legalism in Planning, Zoning, and Land Use Regulatory Practice. Paper presented a the Joint Meeting of the Law and Society Association and the Canadian Law and Society Association, Vancouver, B.C., May 30-June 2.

Burke, Thomas F. 2002. Lawyers, Lawsuits and Legal Rights: The Battle over Litigation in American Society. Berkeley and Los Angeles: University of California Press. 
Busch, Christopher, David L. Kirp, and Daniel Schoenholz. 1998-99. Taming Adversarial Legalism: The Port of Oakland's Dredging Saga Revisited. New York University Journal of Legislation and Public Policy 2:179-216.

Church, Thomas W., and Robert Nakamura. 1993. Cleaning up the Mess: Implementation Strategies in Superfund. Washington, D.C.: Brookings Institution.

Coglianese, Cary, and Jennifer Nash. 2001. Regulating from the Inside: Can Environmental Management Systems Achieve Policy Goals? Washington, D.C.: Resources for the Future.

Cooter, Robert, and Tom Ginsburg. 1996. Comparative Judicial Discretion: An Empir ical Test of Economic Models. International Review of Law and Economics 16:295313.

Darbyshire, Penny. 1997a. An Essay on the Importance and Neglect of the Magistracy. Criminal Law Review 1997:627-43.

- 1997b. For the New Lord Chancellor-Some Causes for Concern about Magistrates. Criminal Law Review 1997:861-74.

Derthick, Martha A. 2002. Up in Smoke: From Legislation to Litigation in Tobacco Politics. Washington, D.C.: CQ Press.

Edelman, Lauren, Steven Abraham, and Howard Erlanger. 1992. Professional Construction of Law: The Inflated Threat of Wrongful Discharge. Law and Society Review 26: $47-84$.

Epp, Charles R. 1998. The Rights Revolution: Lawyers, Activists, and Supreme Courts in Comparative Perspective. Chicago: University of Chicago Press.

- 2003. The Judge over Your Shoulder: Is Adversarial Legalism Exceptionally American? Law $\&$ Social Inquiry 28 (3): 743-70.

Feeley, Malcolm M., and Setsuo Miyazawa, eds. 2002. The Japanese Adversary System in Context: Controversies and Comparisons. New York: Palgrave/Macmillan.

Feldman, Eric. 2000. Blood Justice: Courts, Conflict and Compensation in Japan, France and the United States. Law and Society Review 34:651-702.

Frase, Richard S. 1990. Comparative Criminal Justice as a Guide to American Law Reform: How Do the French Do It. How Can We Find Out, and Why Should We Care? Califormia Law Review 78:542-683.

Frase, Richard, and Thomas Weigend. 1995. German Criminal Justice. Boston College International and Comparative Law Review 18:317-60.

Friedman, Lawrence. 1975. The Legal System: A Social Science Perspective. New York: Russell Sage Foundation.

Galanter, Marc. 1983. Reading the Landscape of Disputes: What We Know and Don't Know (and Think We Know) about Our Allegedly Contentious and Litigious Society. UCLA Law Review 31:4-71.

Gelb, joyce. 2000. The Equal Employment Opportunity Law: A Decade of Change for Japanese Women. Law and Policy 20:385-407

Gottschall, John. 1986. Reagan's Appointments to the U.S. Courts of Appeals. Judicature, June/July, 49-54.

Gunningham, Neil, Robert A. Kagan, and Dorothy Thornton. 2003. Shades of Green: Business, Regulation, and Environment. Stanford, Calif.: Stanford University Press.

Hamilton, V. Lee, and Joseph Sanders. 1992. Everyday Justice: Responsibility and the Individual in the United States and Japan. New Haven, Conn.: Yale University Press.

Hanf, Kenneth, and Cor Smits. 1991. Maintenance Dredging in the Port of Rotterdam: Trading Off Environmental Quality and Economic Development. Paper presented at Annual Meeting, Law and Society Association, Amsterdam, June 26-29.

Hensler, Deborah R. et al. 1991. Compensation for Accidental Injuries in the United States. Santa Monica, Calif.: RAND Institute for Civil Justice. 
Hermann, Joachim. 1992. Bargaining Justice-a Bargain for German Criminal Justice? University of Pittsburgh Law Review 53:755-76.

Hughes, Graham. 1984. English Criminal Justice: Is It Better Than Ours? Arizona Law Review 27:507.

leetswaart, Heleen. 1990. The International Comparison of Court Caseloads: The Experience of the European Working Group. Law and Society Review 24:571-93.

Johnson, David T. 1998. The Organization of Prosecution and the Possibility of Order. Law and Society Review 32:247-308.

- 1999. The Japanese Way of Justice: Prosecuting Crime in Japan. New York: Oxford University Press.

. 2003. American Law in Japanese Perspective. Law \& Social Inquiry 28 (3): 77198.

Jost, Timothy Stoltzfus. 1998. Health Care Rationing in the Courts: A Comparative Study. Hastings International and Comparative Law Review 21:639-714.

Kagan, Robert A. 1984. The Routinization of Debt Collection: An Essay on Social Change and Conflict in the Courts. Law and Society Review 18:324-71.

- 1994. Do Lawyers Cause Adversarial Legalism? Law and Social Inquiry 19:1-62. - 1995. What Sociolegal Scholars Should Do When There Is Too Much Law to Study. Journal of Law and Society 22:140-48.

. 1997. Should Europe Worry about Adversarial Legalism? Oxford Joumal of Legal Studies 17:165-84.

-1998-99. Adversarial Legalism: Tamed or Still Wild? New York University Journal of Legislation and Policy 2:217-45.

2000. Comparing National Styles of Regulation in Japan and the United States. Law and Policy 22:225-44.

- 2002. Adversarial Legalism and American Criminal Justice. In Feeley and Miyazawa 2002.

Kagan, Robert A., and Lee Axelrad, eds. 2000. Regulatory Encounters: Multinational Corporations and American Adversarial Legalism. Berkeley and Los Angeles: University of California Press.

Kagan, Robert A., and William Nelson. 2001. The Politics of Tobacco Regulation in the United States. In Rabin and Sugarman 2001.

Kagan, Robert A., Martin Krygier, and Kenneth Winston, eds. 2002. Legality and Community: On the Intellectual Legacy of Philip Selznick Lanham, Md. and Berkeley, Calif.: Rowman \& Littlefield and Berkeley Public Policy Press.

Kirp, David L. 1979. Doing Good by Doing Little: Race and Schooling in Britain. Berkeley and Los Angeles: University of California Press.

- 1982. Professionalization as a Policy Choice: British Special Education in Comparative Perspective. World Politics 34:137-74.

Kritzer, Herbert. 1991. Propensity to Sue in England and the United States of America: Blaming and Claiming in Tort Cases. Journal of Law and Society 18:400-423.

Langbein, John. 1979. Land without Plea Bargaining: How The Germans Do lt. Michigan Law Review 78:204-25.

- 1985. The German Advantage in Civil Procedure. University of Chicago Law Review 52:823-66.

. 1994. Will Contests. Yale Law Joumal 103:2039-48.

Levin, Mark A. 1997. Smoke around the Rising Sun: An American Look at Tobacco Regulation in Japan. Stanford Law and Policy Review 8:99-123.

Machura, Stefan. 2000. Justice Evaluations by Lay German Assessors. Paper presented at Annual Meeting of the Law and Society Association, Miami Beach, Florida.

Marcus, Richard L. 2002. Reform through Rulemaking? Washington University Law Quarterly 80:901-44. 
Markesinis, Basil. 1990. Litigation-Mania in England, Germany, and the USA: Are We So Very Different? Cambridge Law Joumal 49:233-76.

Mashaw, Jerry. 1983. Bureaucratic Justice: Managing Social Security Disability Claims. New Haven, Conn.: Yale University Press.

McClosky, Herbert, and Alida Brill. 1983. Dimensions of Tolerance: What Americans Believe about Civil Liberties. New York: Russell Sage Foundation.

Melnick, R. Shep. 1995. Separation of Powers and the Strategy of Rights: The Expansion of Special Education. In The New Politics of Public Policy, ed. Marc Landy and Martin Levin. Baltimore, Md.: Johns Hopkins Press.

Milhaupt, Curtis, and Geoffrey Miller. 2000. Regulatory Failure and the Collapse of Japan's Home Mortgage Lending Industry: A Legal and Economic Analysis. Law and Policy 22:245-90.

Miller, Richard, and Austin Sarat. 1981. Grievances, Claims and Disputes: Assessing the Adversary Culture. Law and Society Review 15:525-66.

Moe, Terry M. 1989. The Politics of the Bureaucratic State. In Can the Government Govem? ed. J.Chubb and P. Peterson. Washington, D.C.: Brookings Institution.

Muller, Ingo. 1991. Hitler's Justice: The Courts of the Third Reich. Cambridge, Mass.: Harvard University Press.

Nelken, David. 2003. Beyond Compare? Criticizing "The American .Way of Law." Law \& Social Inquiry 28 (3): 799-832.

Nielsen, Laura Beth. 1999. Paying Workers or Paying Lawyers: Employee Termination Practices in the United States and Canada. Law and Policy: 21:247-82.

Niemeijer, Bert. 1989. Urban Land-Use and Building Control in The Netherlands: Flexible Decisions in a Rigid System. Law and Policy 11:121-52.

Nonet, Philippe. 1969. Administrative Justice. New York: Russell Sage Foundation. 1976. For Jurisprudential Sociology. Law and Society Review 10:525-45.

Ochoa, Michael F. 1997. A Culture of Law: Street-Level Decision Making in the Social Security Administration. Ph.D. diss., University of California, Berkeley.

Peters, Antonie. 1992. Some Comparative Observations on the Criminal Process in Holland and Japan. Journal of the Japan-Netherlands Institute 4:247.

Pizzi, William. 1999. Trials without Truth. New York: New York University Press.

Pollitz, K., J. Crowley, and E. Bangit. 2002. Assessing State External Review Programs and the Effects of Pending Federal Patients' Rights Legislation. Washington, D.C.: Georgetown University Institute for Health Care Research and Policy.

Quam, Lois, Robert Dingwall, and Paul Fenn. 1987. Medical Malpractice in Perspective. British Medical Joumal 294:1529.

Rabin, Robert 2001. The Third Wave of Tobacco Tort Litigation. In Rabin and Sugarman 2001.

Rabin, Robert, and Stephen Sugarman, eds. 2001. Regulating Tobacco. New York: Oxford University Press.

Ramseyer, J. Mark, and Eric B. Rasmusen. 2001. Why Are Japanese Judges So Conservative in Politically Charged Cases? American Political Science Review 95 (2): 331 44.

Saguy, Abigail C. 2000. Employment Discrimination or Sexual Violence? Defining Sexual Harassment in American and French Law. Law and Society Review 34:10911127.

Sanders, Joseph. 2003. Adversarial Legalism and Civil Litigation: Prospects for Change. Law $\mathbb{E}$ Social Inquiry 28 (3): 719-42.

Scherer, Nancy. 2001. Who Drives the Ideological Makeup of the Lower Federal Courts in a Divided Government? Law and Society Review 35:191-218.

Scholz, John T. 1984. Cooperation, Deterrence and the Ecology of Regulatory Enforcement. Law and Society Review 18:179-224. 
Schwartz, Gary. 1991. Product Liability and Medical Malpractice in Comparative Context. In The Liability Maze, ed. Peter Huber and Robert Litan. Washington, D.C.: Brookings Institution.

Scruggs, Lyle A. 1999. Institutions and Environmental Performance in Seventeen Western Democracies. British Joumal of Political Science 29.

Segal, Jeffrey, and Harold J. Spaeth. 1993. The Supreme Court and the Attitudinal Model. New York: Cambridge University Press.

Sellers, Jeffery M. 1995. Litigation as a Local Political Resource: Courts in Controversies over Land Use in France, Germany and the United States. Law and Society Review 29:475-516.

Selznick, Philip. 1969. Law, Society and Industrial Justice. New York: Russell Sage Foundation.

Somaya, Deepak. 2000. Obtaining and Protecting Patents in the United States, Europe and Japan. In Kagan and Axelrad 2000.

Tanase, Takao. 1990. The Management of Disputes: Automobile Accident Compensation in Japan. Law and Society Review 24:651-88.

Ulc, Otto. 1972. The Judge in a Communist State. Columbus: Ohio State University Press.

Upham, Frank K. 1987. Law and Social Change in Postwar Japan. Cambridge, Mass.: Harvard University Press

Verweij, Marco. 2000. Why Is the River Rhine Cleaner than the Great Lakes (Despite Looser Regulation)? Law and Society Review 34:1007-54.

Vinke, Harriet, and Ton Wilthagen. 1992. The NonMobilization of Law by Asbestos Victims in The Netherlands: Social Insurance versus Tort-Based Compensation. Working paper. Amsterdam: Hugo Sinzheimer Isntiture, University of Amsterdam.

Vogel, David. 1986. National Styles of Regulation: Environmental Policy in Great Britain and the United States. Ithaca, N.Y.: Cornell University Press.

Wallace, David. 1995. Environmental Policy and Industrial Innovation: Strategies in Europe, the U.S., and Japan. London: Royal Institute of International Affairs, Earthscan Publications.

Warren, Susan. 2003a. Asbestos Quagmire. Wall Street Journal, 27 January, B1.

. 2003b. Swamped Courts Practice Plaintiff Triage. Wall Street Journal, 27 January, B1.

Weigend, Thomas. 1980. Continental Cures for American Ailments: European Criminal Procedure as a Model for Law Reform. In Crime and Justice, Vol. 2, ed. Norval Morris and Michael Tonry, 381-428. Chicago: University of Chicago Press.

Welles, Holly, and Kirsten Engel. 2000. A Comparative Study of Solid Waste Landfill Regulation: Case Studies from the United States, the United Kingdom, and the Netherlands. In Kagan and Axelrad 2000.

Wilensky, Harold L. 2002. Rich Democracies: Political Economy, Public Policy, and Performance. Berkeley and Los Angeles: University of California Press.

Wilson, James Q. 1997. Criminal Justice in England and America. Public Interest, Winter, 3.

Wokutch, Richard E. 1992. Worker Protection, Japanese Style: Occupational Safety and Health in the Auto Industry. Ithaca, N.Y.: ILR Press. 